\title{
Methods of lab silos sealing and fermentation characteristics and aerobic stability of sugarcane silage treated with microbial additive
}

\section{Charles Ortiz Novinski ${ }^{1}$, Daniel Junges ${ }^{1}$, Patrick Schmidt ${ }^{2}$, Paulo Rossi Junior ${ }^{2}$, João Paulo Gomes de Carvalho ${ }^{3}$, Rodrigo de Almeida Teixeira ${ }^{2}$}

\footnotetext{
1 Programa de Mestrado em Ciência Veterinária - Universidade Federal do Paraná, Curitiba/PR.

2 Departamento de Zootecnia - Universidade Federal do Paraná, Curitiba/PR.

${ }^{3}$ Curso de graduação em Zootecnia - Universidade Federal do Paraná, Curitiba/PR.
}

\begin{abstract}
The present experimental assay evaluated the effect of lab silo sealing methods on the ensilage of the sugarcane, with or without microbial additives (Lactobacillus plantarum and Propionibacterium acidipropionici). Twentyliter plastic buckets were used as experimental silos, which were sealed with either a polyethylene sheet (silo cover with a mesh size of $200 \mu \mathrm{m}$ ) or an appropriate plastic lid equipped with Bunsen valve. Silos were stored for 30, 60, or 90 days. Fermentative losses, chemical composition, organic acids, ethanol and aerobic stability were evaluated. The sealing method employed did not influence most of evaluated variables, showing a small decrease of effluent production in silos covered with polyethylene sheet. The microbial additive did not avoid dry matter (DM) fermentative losses in sugarcane silages $\left(216 \mathrm{~g} \mathrm{~kg}^{-1}\right)$, nor affected aerobic stability (44.6 hours). The levels of neutral and acid detergent fiber of fresh sugarcane increased after ensiling due to DM losses as gases and effluent. The ethanol content of silages was not influenced by treatments (mean $146 \mathrm{~g} \mathrm{~kg}^{-1}$ of DM). The sealing methods of experimental silos were not affected by the evaluated variables; polyethylene sheet and plastic lid show the same performance on the fermentative model and both methods represent well the conditions of large scale farm silos.
\end{abstract}

Key Words: ensilage, ethanol, Lactobacillus plantarum, plastic sheet, Propionibacterium acidipropionici

\section{Introduction}

Research on ensilage in Brazil has progressed considerably following the frequent use of experimental silos (lab silos), including the widespread usage of PVC pipes (Ávila et al., 2010), plastic drums (Amaral et al., 2009), plastic buckets with a capacity of five liters (Balieiro Neto et al., 2009) or 20 liters (Pedroso et al., 2007), as well as other methods. The use of lab silos allows for measuring the quality and fermentation losses in the form of gases and effluents (Jobim et al., 2007).

A recurring criticism to the use of lab silos involves their optimized sealing conditions, which might not be representative of the conditions of large-scale ensilage, particularly with respect to the effects of additives in the ensiling process. Bernardes et al. (2010) assessed the effect of different plastic covers on silos and concluded that sealing with a plastic film of lower permeability to oxygen improved the fermentative potential and reduced deterioration in corn ensilage.

According to Schmidt et al. (2007), losses from the yeast metabolism on sugarcane can reach up to $490 \mathrm{~g} \mathrm{~kg}^{-1}$ of the dry matter (DM). Ávila et al. (2010) assessed the microbial population dynamics in sugarcane ensilage and concluded that the growth of yeast populations depends on the sugarcane variety and the time of fermentation, and that the predominant species in sugarcane are different from those yeast species present in other forages.

The implications of the use of additives on sugarcane ensilage remain poorly understood and experimental results are still inconclusive. In a literature review, Schmidt (2009) detected considerable variation on the efficiency of additives among different experimental conditions and suggested that such variation stems from differences in the epiphytic populations of the forage, which would affect the action mechanism and the magnitude of the response to the application of an additive. Siqueira et al. (2010) showed that the change in the epiphytic population due to burning the sugarcane cause a shift in the response pattern to the applied additives.

The use of additives based on heterolactic microorganisms during ensilage of sugarcane is based on the assumption that they will produce either acetic or propionic acids, which are potential inhibitors of yeast fermentation activity (Danner et al., 2003). The objective of this study was to evaluate the ensilage of sugarcane with and without microbial additive under two methods of sealing the lab silos. 


\section{Material and Methods}

The trial was carried out in a rural property in Santo Antônio da Platina, state of Paraná, Brazil, and data collection and analysis were done at the Centro de Pesquisa em Forragicultura (CPFOR) of the Departamento de Zootecnia of the Universidade Federal do Paraná (UFPR), in Curitiba, Paraná, Brazil.

The variety of sugarcane used in the study was RB72454, harvested in November 11, 2009, when it was at an appropriate stage of maturation $\left(21.1^{\circ} \mathrm{Brix}\right)$, using forage harvester coupled to a tractor and set up to chop length of $10 \mathrm{~mm}$.

The lab silos used were 20-L plastic buckets equipped with an apparatus to measure losses by effluents according to the protocol described by Jobim et al. (2007). Two sealing methods were used: Lid - a lid equipped with a Bunsen valve to allow for the release of gases; and Sheet - sealing with a polyethylene film $(200 \mu \mathrm{m}$ black sheet $)$, suitable for silo sealing, attached to the silo with adhesive tape.

Microbial inoculation was assessed according to the following categories: Control - without additive; Additive - commercial additive containing strains of Lactobacillus plantarum and Propionibacterium acidipropionici $\left(2.4 \times 10^{5}\right.$ Colony Forming Units - CFUs/g of fresh natter - FM). The additive was applied using the dosage recommended by the manufacturer $\left(4 \mathrm{~g} \mathrm{t}^{-1}\right.$ of $\left.\mathrm{FM}\right)$, diluted in distilled water ( $4 \mathrm{~L} / \mathrm{t}$ of FM) and uniformly pulverized on the forage immediately prior to filling the silos. The control group received the same amount of water. Later, the material in the lab silos was compacted to reach a bulk density of $600 \mathrm{~kg} \mathrm{~m}^{-3}$.

Three storage periods (30,60, and 90 days) were used, with four replicates per treatment, where each silo was considered an experimental unit, in a $2 \times 2 \times 3$ factorial experimental design (two sealing methods, with or without additive, and three storage periods), for a total of 48 experimental units.

Silos were weighted before and after being filled. They were then closed, sealed with adhesive tape and placed in a covered barn until opening. After the storage periods (either 30,60 , or 90 days), silos were weighted again and opened. The upper 5 -cm layer was discarded and the silage was removed and homogenized in plastic bags for collection of samples. The remaining forage was used to assess aerobic stability.

Losses of DM in the form of gases were calculated based on the difference between initial and final absolute weights of DM in lab silos, and effluents, according to the difference between initial and final weight of silos containing the apparatus for collecting effluents (Jobim et al., 2007).
The total loss of DM was calculated by the difference between the DM weight of the forage placed in each silo and the silage obtained at the opening, not considering the produced effluent.

Three samples were obtained from each silage. One of the samples was oven-dried $\left(55^{\circ} \mathrm{C}, 72 \mathrm{~h}\right)$ and then processed in a Wiley stationary mill with a $1-\mathrm{mm}$ mesh size sieve for chemical analyses. Other sample was used to measure the $\mathrm{pH}$ in water extract. Finally, the third aliquot was pressed to obtain the silage juice used to determine its volatile organic compounds.

Chemical analyses were carried out at the Laboratório de Nutrição Animal of the Departamento de Zootecnia, Universidade Federal do Paraná. The content of DM, ash and crude protein $(\mathrm{CP})$ were determined according to the methods described by Silva \& Queiroz (2002), and the levels of neutral detergent fiber (NDF) and acid detergent fiber (ADF) were assessed using the ANKON sequential method according to Holden (1999).

Fresh samples of sugar cane from each treatment were used to determine the level of DM and the chemical composition, which showed, on average (DM basis): $287 \mathrm{~g} \mathrm{~kg}^{-1}$ of DM; $27.1 \mathrm{~g} \mathrm{~kg}^{-1}$ of CP; $585 \mathrm{~g} \mathrm{~kg}^{-1}$ of NDF; $327 \mathrm{~g} \mathrm{~kg}^{-1}$ of ADF, and $54.6 \mathrm{~g} \mathrm{~kg}^{-1}$ of ash.

In order to assess the $\mathrm{pH}, 25 \mathrm{~g}$ of silage were added to $225 \mathrm{~mL}$ of deionized water, and the $\mathrm{pH}$ value measured directly with a digital potentiometer model WTW 330i according to Kung Junior et al. (1984).

The silage juice was acidified ( $1 \mathrm{~mL}$ of formic acid PA: $5 \mathrm{~mL}$ of juice), frozen and sent to the the Laboratório de Análise de Alimentos of the Faculdade de Medicina Veterinária e Zootecnia of the Universidade de São Paulo (FMVZ-USP), in Pirassununga, São Paulo, to determine the organic acids (lactic, acetic, propionic, and butyric acids) and ethanol using gas chromatography.

The aerobic stability was assessed by monitoring the temperature of silages exposed to air, according to the methodology described by Kung Junior et al. (2000). Three $\mathrm{kg}$ of silage from each experimental unit were placed in open plastic buckets and kept in a temperature-controlled room at $25 \pm 1{ }^{\circ} \mathrm{C}$ for $120 \mathrm{~h}$. Temperature was measured using thermometers inserted in the center of the mass, with temperature recordings at every $6 \mathrm{~h}$. A sample was removed from each experimental unit at the beginning and the end of the evaluation period to determine the DM content. The variables measured were: aerobic stability, defined as the time in hours to elevate the temperature by $2^{\circ} \mathrm{C}$ in relation to the room; Maximum temperature reached by the mass, in ${ }^{\circ} \mathrm{C}$; Time (hours) to reach maximum temperature; dry matter losses from zero to $120 \mathrm{~h}$. 
A completely randomized experimental design was adopted in every assessment. The results were subjected to analysis of variance, and comparisons between means were conducted using the Tukey test, with a $5 \%$ significance level, using the PROC GLM routine in the SAS statistical package (Statistical Analysis System, version 9.1.3).

\section{Results and Discussion}

The chemical composition of sugarcane before ensilage was similar to that observed by Balieiro Neto et al. (2009), although the CP level was below the one recorded in that study (36 g kg-1 DM). Likewise, silage composition was similar to the values obtained by Pedroso et al. (2007) for sugarcane silage with or without additives, and by Ávila et al. (2010) for silage of the same variety of sugarcane (RB72-454).

There was no interaction between storage period and the assessed treatments for any of the studied variables, except for the content of propionic acid in the silage (Table 4).

There was no statistically significant effect $(\mathrm{P}>0.05)$ of the additive on the chemical composition and fermentative loss variables. The sealing methods (Lid or Sheet) influenced only the effluents production, indicating that the fermentative process was similar in either type of silo sealing, producing silages with similar characteristics (Table 1).

There was an average decrease of $47 \mathrm{~g} \mathrm{~kg}^{-1}$ in the content of DM in silages in relation to the fresh sugarcane. Likewise, the content of cell wall components of the silages (NDF and ADF), as well as the content of $\mathrm{CP}$ and ash increased after the ensiling process. These effects are probably due to the loss of soluble carbohydrates during the fermentative phase, as indicated by the high loss of DM (217 $\left.\mathrm{g} \mathrm{kg}^{-1}\right)$. Pedroso et al. (2007) also found an increase in the NDF and ADF in sugarcane silages using chemical and biological additives. Although the increase in the fiber content is also related to the consumption of soluble carbohydrates, the correlation between this effect and the decrease in the nutritional value cannot be precisely determined, because of the transformation of the soluble carbohydrates into volatile fatty acids without generating energetic losses to the animals, but with the loss of DM due to drying the samples in the oven.

The total DM losses are consistent with the results from most of the studies that assessed losses in these materials. In a literature review, Schmidt (2009) asserted that out of 12 studies that evaluated dry matter losses in sugarcane silage with $L$. plantarum, 10 found evidence that inoculation increased losses, at an average of $128 \mathrm{~g} \mathrm{~kg}^{-1}$. According to this author, average losses in 19 trials with sugarcane silage without additives are $267 \mathrm{~g} \mathrm{~kg}^{-1}$ of DM, higher than that observed in the present assay.

These losses are caused by the metabolism of yeast, which consumes great part of the soluble carbohydrates and lactate and produces $\mathrm{CO}_{2}$, water, ethanol, and energy (Moon, 1983; McDonald et al., 1991). Due to the high growth of yeast on sugarcane, fermentative losses of DM during ensilage are higher than all other forage species conserved using this method. Ávila et al. (2010) isolated nine distinct species of yeast from samples of five sugarcane silages and observed that most of them assimilated lactate and all species grew well in a pH lower than 3.3. The RB72454 variety, the same used in this study was noticed by the authors as with higher occurrence of Torulaspora debrueckii and Pichia anomala, which, under conditions of anaerobiosis, obtain energy from the fermentation of sugars, producing 2 moles of $\mathrm{CO}_{2}$ and two molecules of water for each mol of glycose that is fermented into ethanol (McDonald et al., 1991).

The production of effluent in silages can be related to the level of DM of the plant, the cell wall rupture and bulk density (Alli et al., 1985), as well as to the formation of water

Table 1 - Fermentative losses, $\mathrm{pH}$, and chemical composition of sugarcane silage according to the sealing method of lab silos

\begin{tabular}{|c|c|c|c|c|c|c|}
\hline \multirow[b]{2}{*}{ Variables } & \multicolumn{2}{|c|}{ Sealing $^{1}$} & \multirow[b]{2}{*}{ Mean } & \multirow[b]{2}{*}{ SEM } & \multicolumn{2}{|c|}{ Effects $^{2}$} \\
\hline & Lid & Sheet & & & $\mathrm{S}$ & $\mathrm{T} \times \mathrm{S}$ \\
\hline Dry matter, $\mathrm{g} \mathrm{kg}^{-1}$ & 240 & 241 & 240 & 0.5 & 0.262 & 0.753 \\
\hline Crude protein, $\mathrm{g} \mathrm{kg}^{-1}$ of DM & 30.9 & 30.8 & 31.0 & 0.4 & 0.246 & 0.732 \\
\hline $\mathrm{NDF}, \mathrm{g} \mathrm{kg}^{-1}$ of $\mathrm{DM}$ & 719 & 721 & 720 & 3.0 & 0.356 & 0.381 \\
\hline ADF, $\mathrm{g} \mathrm{kg}^{-1}$ of DM & 419 & 419 & 419 & 2.2 & 0.063 & 0.420 \\
\hline Ash, $\mathrm{g} \mathrm{kg}^{-1}$ of DM & 70 & 69 & 69 & 0.6 & 0.0006 & 0.396 \\
\hline $\mathrm{pH}$ & 3.41 & 3.41 & 3.41 & 0.01 & 0.0005 & 0.059 \\
\hline Effluents, $\mathrm{kg} \mathrm{t} \mathrm{t}^{-1} \mathrm{FM}$ & $27.3 b$ & $33.3 \mathrm{a}$ & 30.3 & 0.86 & 0.014 & 0.071 \\
\hline Gases, $\mathrm{g} \mathrm{kg}^{-1} \mathrm{DM}$ & 193 & 189 & 191 & 17.3 & 0.081 & 0.981 \\
\hline Total DM losses, $\mathrm{g} \mathrm{kg}^{-1}$ & 216 & 217 & 217 & 17.2 & 0.137 & 0.989 \\
\hline
\end{tabular}

SEM - standard error of the mean; S - storage period; $\mathrm{T} \times \mathrm{S}$ - interaction between storage period and treatment; DM - dry matter; NDF - neutral detergent fiber; ADF - acid detergent fiber; FM - fresh matter.

${ }_{1}^{1}$ Means followed by different letters on the same row are statistically different $(\mathrm{P}<0.05)$ according to Tukey test.

2 Probability of error. 
during the fermentation of glycose into ethanol and the decrease of DM content due to losses (McDonald et al., 1991). In this paper, the silos sealed with plastic sheet showed the highest production of effluents, although the levels of DM and the fermentative losses were very similar to silos sealed with lids. The average production of $30.3 \mathrm{~kg}$ of effluent/t FM is consistent with the values observed by Santos et al. (2008), of $31.2 \mathrm{~kg} \mathrm{t}^{-1}$, although the values described in the literature show considerable variation in magnitude, from $0.6 \mathrm{~kg} \mathrm{t}^{-1} \mathrm{FM}$ (Pedroso et al., 2008) to $115.6 \mathrm{~kg} \mathrm{t}^{-1}$ FM (Siqueira et al., 2010).

Although effluent loss is visibly significant in largescale silos, fermentative losses as gases accounted for, on average, $88 \%$ of the dry matter losses. In silos sealed with sheets, although there was no escape valve, the gases probably diffused to the environment through the porosity of the plastic sheet, without any bulging or sealing detachment in any experimental unit. Bernardes et al. (2010) found air permeability of $722 \mathrm{~mL} \mathrm{~m}^{-2} \mathrm{day}^{-1}$ for the $200-\mu \mathrm{m}$ polyethylene sheet.

The levels of volatile organic compounds in the silages were not influenced by the method of sealing the lab silos $(\mathrm{P}>0.05)$. The inoculation with the additive shifted the level of lactic and acetic acids in the silage in relation to the control group (Table 2).

Silages with additive showed the highest concentration of lactic acid due to the population of L. plantarum, which is a potent homofermentative bacterium. Inoculation decreased the acetic acid content in relation to the control silage, probably due to the competitive advantage and the rapid acid production of homolactic bacteria in relation to the heterolactic ones. Thus, the population of P. acidipropionici inoculated in the ensilage does not seem to have been efficient in growing, once there was no increase in propionic acid content in the silage with the additive. Propionibacterium is characterized by slow metabolism and growth inhibition at $\mathrm{pH}$ lower than 4 (Filya et al., 2004). In this trial, the propionic acid content remained close to those reported by Schmidt et al. (2007), at an average of $2.1 \mathrm{~g} \mathrm{~kg}^{-1}$ and below the $12 \mathrm{~g} \mathrm{~kg}^{-1}$ level of DM verified by Freitas et al. (2006).

Only traces of butyric acid were found in silages that did not show clostridic fermentation due to the rapid decrease in $\mathrm{pH}$ and adequate content of DM in the forage.

The ethanol content was fairly high for either silages, with a tendency $(\mathrm{P}=0.08)$ towards a higher concentration in inoculated ensilage (156 g kg $\mathrm{g} \mathrm{of}^{-1}$ DM) in comparison with the control ensilage ( $137 \mathrm{~g} \mathrm{~kg}^{-1}$ of DM). However, this effect did not influence the gas production or the dry matter losses, which were similar in both silages.

The assessment of volatile compounds allows for inferring a predominance of a typically homolactic fermentation in the silages, particularly in the inoculated ones, which disfavored microorganisms that generate acetic and propionic acids and stimulated the growth of yeasts. Yeasts are capable of growing under reduced $\mathrm{pH}$ conditions and convert carbohydrates and lactate into ethanol (McDonald et al., 1991; Ávila et al., 2010).

Schmidt et al. (2011) evaluated an additive composed of the homolactic L. plantarum and Enterococcus faecium, and the heterolactic L. brevis in sugarcane ensilage, and showed a predominance of homolactic fermentation, with an increase in lactic acid and ethanol content, and dry matter losses (43 $\mathrm{g} \mathrm{kg}^{-1}$ of DM; $186 \mathrm{~g} \mathrm{~kg}^{-1}$ of DM, and $272 \mathrm{~g} \mathrm{~kg}^{-1}$, respectively), in relation to the control (36 $\mathrm{g} \mathrm{kg}^{-1}$ of the DM; $144 \mathrm{~g} \mathrm{~kg}^{-1}$ of the DM, and $144 \mathrm{~g} \mathrm{~kg}^{-1}$, respectively). Although the additives in both trials are totally different, the recorded effect was similar and consistent with other results available in the literature, thus reinforcing the idea that homolactic fermentation in sugarcane silages is deleterious to the quality of the product.

There was no statistically significant effect of the additive and sealing method (Sheet or Lid) on the measured aerobic stability variables (Table 3 ). However, there were effects of storage period over the most studied measures of stability (Table 4).

Although Filya et al. (2004) asserted that inoculation with $P$. acidipropionici elevates aerobic stability, this

Table 2 - Composition of short-chain fatty acids (acetic, propionic and butyric), lactic acid and ethanol in sugarcane silages

\begin{tabular}{|c|c|c|c|c|c|c|}
\hline \multirow[b]{2}{*}{ Variable } & \multicolumn{2}{|c|}{ Treatment $^{1}$} & \multirow[b]{2}{*}{ Mean } & \multirow[b]{2}{*}{ SEM } & \multicolumn{2}{|c|}{ Effect ${ }^{2}$} \\
\hline & Control & Additive & & & $\mathrm{S}$ & $\mathrm{T} \times \mathrm{S}$ \\
\hline Lactic acid, $\mathrm{g} \mathrm{kg}^{-1} \mathrm{DM}$ & $63 b$ & $68 \mathrm{a}$ & 65 & 0.8 & 0.045 & 0.058 \\
\hline Acetic acid, $\mathrm{g} \mathrm{kg}^{-1} \mathrm{DM}$ & $14 \mathrm{a}$ & $11 \mathrm{~b}$ & 12 & 0.6 & 0.307 & 0.554 \\
\hline Propionic acid, $\mathrm{g} \mathrm{kg}^{-1} \mathrm{DM}$ & 2.0 & 1.1 & 1.5 & 0.4 & 0.0001 & 0.043 \\
\hline Butiric acid, $\mathrm{g} \mathrm{kg}^{-1} \mathrm{DM}$ & 0.0 & 0.0 & 0.0 & 0.0 & 0.889 & 0.972 \\
\hline Ethanol, $\mathrm{g} \mathrm{kg}^{-1} \mathrm{DM}$ & 137 & 156 & 147 & 7.0 & 0.164 & 0.154 \\
\hline
\end{tabular}

Means followed by different letters on the same row are statistically different $(\mathrm{P}<0.05)$ according to Tukey test.

SEM - standard error of the mean; $\mathrm{S}$ - storage period; $\mathrm{T} \times \mathrm{S}$ - interaction between storage period and treatment; DM - dry matter.

${ }^{1}$ Control - without additive; Additive - Lactobacillus plantarum + Propionibacteruim acidipropionici $\left(2.4 \times 10^{5} \mathrm{CFUs} / \mathrm{g}\right)$.

2 Probability of error. 
effect was not confirmed in the present study, probably due to the limited development of this microorganism in sugarcane silages. The same effect was observed by Siqueira et al. (2010), when the additive composed of $L$. plantarum and P. acidipropionici did not improve aerobic stability of sugarcane silage.

Both of the sealing methods adopted produced silages with very similar characteristics (Table 1), as reflected in the aerobic stability measures, which showed similar values for all studied variables.

The average level of aerobic stability ( 45 hours) in this trial is similar to the 56 hours recorded by Mendes et al. (2008) and 39 hours recorded by Schmidt et al. (2011), but lower than the 90 hours of stability obtained by Amaral et al. (2009b), for sugarcane without additives. However, the dry matter losses for $120 \mathrm{~h}\left(59 \mathrm{~g} \mathrm{~kg}^{-1}\right)$ were similar to that observed by Amaral et al. (2009b) of $51 \mathrm{~g} \mathrm{~kg}^{-1}$ in the same period. This indicates that aerobic stability is not a good indicator of losses by aerobiosis, when assessed during a long period of time $(120 \mathrm{~h})$.

Silages stored for 60 days showed the lowest values of $\mathrm{pH}$ (Table 4). This effect coincides with the lower production of effluents after 60 days, which could have led to lower acid leaching. Haigh (1999) investigated effluent composition produced by 45 grass silages and showed lactic acid content in the effluent varying between 9.8 and $19.0 \mathrm{mg} \mathrm{mL}^{-1}$.
The content of propionic acid was markedly reduced in relation to the increase in storage period. This effect suggests the use of this acid in secondary fermentation and in the metabolism of other microorganisms. A similar effect was detected by Ávila et al. (2009), assessing the fermentative performance of lactic bacterial strains on sugarcane juice inoculated with yeasts as a function of the increase in storage period, for 11 out of 13 investigated strains. McDonald et al. (1991) indicated that, under aerobic conditions, yeasts are capable of using organic acids such as lactate, acetate, citrate, malate and propionate, but under anaerobic conditions they only obtain energy from sugar fermentation. Thus, the fate of this acid during sugarcane ensilage is still unknown.

Silos opened after 30 days of storage showed lower aerobic stability, with $35 \mathrm{~h}$ necessary to disrupt stability (elevation in $2{ }^{\circ} \mathrm{C}$ in mass temperature). Heat production is the result of microbial activity, which oxidates dry matter, leading to losses in the form of carbon dioxide. Materials that remained stored longer (60 and 90 days) showed higher stability (50.5 and 48.5 hours, respectively), possibly as a result of increased loss of carbohydrates during the fermentative phase.

The number of hours necessary to reach maximum temperature increased with storage time, indicating that mass warming was slower in silages stored for a longer period of time, probably due to the lower availability of

Table 3 - Aerobic stability of sugarcane ensilages according to the method of sealing the experimental silos

\begin{tabular}{|c|c|c|c|c|c|c|}
\hline \multirow[b]{2}{*}{ Variables } & \multicolumn{2}{|c|}{ Sealing ${ }^{1}$} & \multirow[b]{2}{*}{ Mean } & \multirow[b]{2}{*}{ SEM } & \multicolumn{2}{|c|}{ Effects $^{2}$} \\
\hline & Lid & Sheet & & & $\mathrm{S}$ & $\mathrm{T} \times \mathrm{S}$ \\
\hline AE, hours & 43 & 46 & 45 & 2.0 & 0.0001 & 0.972 \\
\hline HTMax, hours & 69 & 74 & 71 & 2.2 & 0.0001 & 0.794 \\
\hline $\mathrm{TMax}^{\circ}{ }^{\circ} \mathrm{C}$ & 40.9 & 41.1 & 41.0 & 0.2 & 0.0002 & 0.270 \\
\hline DML $0-120$ hours, $\mathrm{g} \mathrm{kg}^{-1}$ & 56 & 63 & 59 & 12 & 0.454 & 0.775 \\
\hline
\end{tabular}

SEM - standard error of the mean; S - storage period; T $\times$ S - interaction between storage period and treatment; AE - aerobic stability; HTMax - hours to reach maximum temperature; TMax - maximum temperature reached; DML 0-120 hours - dry matter losses during the aerobic exposition.

${ }^{1}$ Means followed by different letters on the same row are statistically different $(\mathrm{P}<0.05)$ according to Tukey test.

2 Probability of error.

Table 4 - Chemical composition, $\mathrm{pH}$ and aerobic stability of sugarcane silages as a function of storage period

\begin{tabular}{|c|c|c|c|c|c|}
\hline \multirow[b]{2}{*}{ Variable } & \multicolumn{3}{|c|}{ Storage period (days) ${ }^{1}$} & \multirow[b]{2}{*}{ Mean } & \multirow[b]{2}{*}{ SEM } \\
\hline & 30 & 60 & 90 & & \\
\hline Ash, $\mathrm{g} \mathrm{kg}^{-1} \mathrm{DM}$ & $65 b$ & $71 \mathrm{a}$ & $70 \mathrm{a}$ & 68 & 8.0 \\
\hline Effluents, $\mathrm{kg} \mathrm{t}^{-1} \mathrm{FM}$ & $31.9 \mathrm{a}$ & $28.1 \mathrm{~b}$ & $30.8 \mathrm{ab}$ & 30.2 & 0.9 \\
\hline Lactic acid, $\mathrm{g} \mathrm{kg}^{-1} \mathrm{DM}$ & $66 \mathrm{ab}$ & $65 \mathrm{~b}$ & $67 \mathrm{a}$ & 65 & 1.4 \\
\hline Propionic acid, $\mathrm{g} \mathrm{kg}^{-1} \mathrm{DM}$ & $4.0 \mathrm{a}$ & $1.0 \mathrm{~b}$ & $0.5 \mathrm{~b}$ & 2.0 & 0.6 \\
\hline $\operatorname{TMax}{ }^{\circ} \mathrm{C}$ & $39.8 b$ & $41.4 \mathrm{a}$ & $41.7 \mathrm{a}$ & 41.0 & 0.27 \\
\hline
\end{tabular}

AE - Aerobic stability; HTMax - hours to reach maximum temperature; TMax - maximum temperature reached; SEM - standard error of the mean; DM - dry matter; FM - fresh matter.

${ }^{1}$ Means followed by different letters on the same row are statistically different $(\mathrm{P}<0.05)$ according to Tukey test. 
residual carbohydrates for the growth of spoiler microorganisms. By day 90 , the ensilage took 93.5 hours to reach $41.7^{\circ} \mathrm{C}$, which was similar to the maximum temperature reached by the ensilage stored for 60 days $\left(41.4{ }^{\circ} \mathrm{C}\right)$. Balieiro Neto et al. (2009) assessed the stability of sugarcane silages inoculated with L. buchneri and recorded 76.8 hours to reach the maximum temperature of $39^{\circ} \mathrm{C}$.

The consumption of soluble carbohydrates during fermentation can explain the effect of storage period over variables aerobic stability and hours to reach maximum temperature. However, this effect is not clear when observing $\mathrm{pH}$ or the content of organic acids over the investigated periods. According to Muck et al. (1991), several factors interfere directly on the silage instability, such as $\mathrm{pH}$, the content of organic acids, the epiphytic populations of yeast and multicellular fungi, as well as the level of residual carbohydrates.

Although bacteria of the genus Propionibacterium are classified as potential agents for improving the aerobic stability of silages (Filya et al., 2004), the responses of these microorganisms to sugarcane silages are still poorly understood (Siqueira et al., 2010). In this trial, silages with the highest content of propionic acid (30 days) were more unstable under aerobiosis.

\section{Conclusions}

The method of sealing lab silos does not influence fermentative losses or silage quality. Lactobacillus plantarum and Propionibacterium acidipropionici are not efficient in avoiding losses, neither in the anaerobic phase nor in the aerobic exposure of the silages. Increasing storage period does not avoid fermentative losses, but improves aerobic stability of sugarcane silages.

\section{References}

ALLI, I.; THIFFAULT C.; BAKER B. et al. A device for monitoring ensilage effluent produced in laboratory silos. Journal of Dairy Science, v.68, n.12, p.3355-3359, 1985.

AMARAL, R.C.; PIRES, A.V.; SUSIN, I. et al. Cana-de-açúcar ensilada com ou sem aditivos químicos: fermentação e composição química. Revista Brasileira de Zootecnia, v.38, n. 8, p.1413-1421, 2009.

AMARAL, R.C.; PIRES, A.V.; SUSIN, I. et al. Cana-de-açúcar in natura ou ensilada com e sem aditivos químicos: estabilidade aeróbia dos volumosos e das rações. Revista Brasileira de Zootecnia, v.38, n.10, p.1857-1864, 2009b.

ÁVILA, C.L.S; BRAVO-MARTINS, C.E.C.; SCHWAN, R.F. Identification and characterization of yeasts in sugarcane silages. Journal of Applied Microbiology, v.109, n.5, p.1677-1686, 2010.

ÁVILA, C.L.S.; PINTO, J.C.; DUARTE, W.F. et al. Screening of lactic acid bacteria for sugarcane ensiling. In: INTERNATIONAL ENSILAGE CONFERENCE, 15., Madison, 2009. Proceedings... Madison: ISC, 2009. p.205-206.
BALIEIRO NETO, G.; FERRARI JUNIOR, E.; NOGUEIRA, J.R. et al. Perdas fermentativas, composição química, estabilidade aeróbia e digestibilidade aparente de silagem de cana-de-açúcar com aditivos químicos e microbiano. Pesquisa Agropecuária Brasileira, v.44, n.6, p.621-630, 2009.

BERNARDES, T.F.; NUSSIO, L.G.; AMARAL, R.C. Top losses in maize ensilage sealed with different plastic films. In: GENERAL MEETING OF EUROPEAN GRASSLAND FEDERATION, 23. 2010, Kiel. Proceedings... Kiel: EGF, 2010. p.428-430.

DANNER, H.; HOLZER, M.; MAYRHUBER, E. et al. Acetic acid increases stability of ensilage under aerobic conditions. Applied and Environmental Microbiology, v.69, n.1, p.562-567, 2003.

FILYA, I.; SUCU, E.; KARABULUT, A. The effect of Propionibacterium acidipropionici, with or without Lactobacillus plantarum, on the fermentatiton and aerobic stability of wheat, sorghum and maize ensilage. Journal of Applied Microbiology, v.97, n.4, p.818-821, 2004.

FREITAS, A.W.P.; PEREIRA, J.C.; ROCHA, F.C. et al. Características da silagem de cana-de-açúcar tratada com inoculante bacteriano e hidróxido de sódio e acrescida de resíduo da colheita de soja. Revista Brasileira de Zootecnia, v.35, n. 1, p.48-59, 2006.

HAIGH, P.M. Effluent production from grass silages treated with additives and made in large-scale bunker silos. Grass and Forage Science, v.54, n.3, p.208-218, 1999.

HOLDEN, L.A. Comparison of methods of in vitro dry matter digestibility for ten feeds. Journal of Dairy Science, v. 82 , n. 8, p.1791-1794, 1999.

JOBIM, C.C.; NUSSIO, L.G.; REIS, R.A. et al. Avanços metodológicos na avaliação da qualidade da forragem conservada. Revista Brasileira de Zootecnia, v.36, p.101-120, 2007 (supl. especial).

KUNG JUNIOR, L.; GRIEVE, D.B.; THOMAS, J.W. et al. Added ammonia or microbial inocula for fermentation and nitrogenous compounds of alfafa ensiled at various percents of dry matter. Journal of Dairy Science, v.67, p.299-306, 1984.

KUNG JUNIOR, L.; ROBINSON, J.R.; RANJIT, N.K. et al. Microbial populations, fermentation end-products, and aerobic stability of corn ensilage treated with ammonia or a propionic acid-based preservative. Journal of Dairy Science, v.83, p.1479-1486, 2000.

McDonald, P.; Henderson, A.R.; Heron, S.J.E. The biochemistry of ensilage. 2.ed. Merlow: Chalcomb Publications, 1991. 340p.

MENDES, C.Q.; SUSIN, I.; NUSSIO, L.G.; et al. Efeito do Lactobacillus buchneri na fermentação, estabilidade aeróbia e no valor nutritivo de silagem de cana-de-açúcar. Revista Brasileira de Zootecnia, v.37, n.12, p.2191-2198, 2008.

MOON, N.J. Inhibition of the growth of acid tolerant yeasts by acetate, lactate and propionate and their synergistic mixtures. Journal of Applied Bacteriology, v.55, p.453-460, 1983.

MUCK, R.E.; PITT, R.E.; LEIBENSPERGER, R.Y. A model of aerobic fungal growth in ensilage. 1. Microbial characteristics. Grass and Forage Science, v.46, p.283-296, 1991.

PEDROSO, A.F.; NUSSIO, L.G.; LOURES, D.R.S. et al. Efeito do tratamento com aditivos químicos e inoculantes bacterianos nas perdas e na qualidade de silagens de cana-de-açúcar. Revista Brasileira de Zootecnia, v.36, n.3, p.558-564, 2007.

PEDROSO, A.F.; NUSSIO, L.G.; LOURES, D.R.S. et al. Fermentation, losses, and aerobic stability of sugarcane silages treated with chemical or bacterial additives. Scientia Agricola v. 65 , n.6, p.589-594, 2008

SANTOS, M.C.; NUSSIO, L.G.; MOURÃO, G.B. et al. Influência da utilização de aditivos químicos no perfil da fermentação, no valor nutritivo e nas perdas de silagens de cana-de-açúcar. Revista Brasileira de Zootecnia, v.37, n.9, p.1555-1563, 2008.

SCHMIDT, P. Improved efficiency of sugarcane ensiling for ruminant supplementation. In: INTERNATIONAL SYMPOSIUM ON 
FORAGE QUALITY AND CONSERVATION, 1., 2009, São Pedro. Proceedings... Piracicaba: FEALQ, 2009. p.47-72.

SCHMIDT, P.; MARI, L.J.; NUSSIO, L.G. et al. Aditivos químicos e biológicos na ensilagem de cana-de-açúcar. 1. Composição química das silagens, ingestão, digestibilidade e comportamento ingestivo. Revista Brasileira de Zootecnia, v.36, n.5, p.1666-1675, 2007. SCHMIDT, P.; ROSSI JUNIOR, P.; JUNGES, D. et al. Novos aditivos microbianos na ensilagem da cana-de-açúcar: composição bromatológica, perdas fermentativas, componentes voláteis e estabilidade aeróbia. Revista Brasileira de Zootecnia, v.40, n.3, p.543-549, 2011.

SILVA, D.J.; QUEIROZ, A.C. Análise de alimentos: métodos químicos e biológicos. 3.ed. Viçosa, MG: Editora UFV, 2002. $235 \mathrm{p}$.

SIQUEIRA, G.R.; REIS, R.A.; SCHOCKEN-ITURRINO R.P. et al Queima e aditivo químicos e bacterianos na ensilagem de cana-deaçúcar. Revista Brasileira de Zootecnia, v.39, n.1, p.103-112, 2010 . 